\title{
CHOOSING TBM FOR TABRIZ SUBWAY USING MULTI CRITERIA METHOD
}

\author{
Kamaladdin Edalat ${ }^{1}$, Mohammad Javad Vahdatirad ${ }^{2}$, Hadi Ghodrat ${ }^{3}$, \\ Sarah Firouzian ${ }^{4}$, Amin Barari $^{5}$ \\ ${ }^{1}$ Faculty of Engineering, Science \& Research branch of Azad University, Tehran, Iran \\ ${ }^{2,5}$ Department of Civil Engineering, Aalborg University, Sohngårdsholmsvej 57, \\ 9000 Aalborg, Denmark \\ ${ }^{3}$ Faculty of Engineering, Tarbiat Moallem University, Tehran, Iran \\ ${ }^{4}$ Department of Civil Engineering, Babol University of Technology, Babol, Iran \\ E-mail: ${ }^{2} j_{-}$vahdati@yahoo.com (corresponding author) \\ Received 31 August 2009; accepted 30 June 2010
}

\begin{abstract}
The world of underground engineering and construction has acquired a wide-ranging and high-level experience on tunnel construction with Tunnel Boring Machines (TBM) and nowadays remarkable progresses are traceable in the number of tunnels that are becoming longer, going deeper, and growing larger in diameter and in other words becoming more difficult to realize. Tabriz-one of the big cities in northern west of Iran has four subway lines which are under construction or investigation. The phase 1 design of Tabriz urban railway line 2 (TURL2) has completely been done. Method statement of this line in the length of about $20 \mathrm{~km}$ and much interference due to tunneling in urban area dictates the application of TBM. Two kinds of TBM such as EPB (earth pressure balance) and SS (slurry shield) are usually used for urban areas. In this paper, the process of choosing TBM for TURL2 using MCA method (Multi Criteria Analysis) is expressed. Generally in this method some technical, economical and environmental parameters affected the TBM type are identified and taken into account by assigned weights related to the case study. Finally the results show that EPB-TBM will be more appropriate choice for TURL2 excavation.
\end{abstract}

Keywords: Mechanized tunneling, TBM, Tabriz subway, Multi Criteria Analysis, TURL2.

\section{Introduction}

Tabriz with $160 \mathrm{~km}^{2}$ area and the population about $1,360,000$ is one of crowded and important cities in north western Iran. According to traffic and transportation studies, 4 light urban railways with the length of $48 \mathrm{~km}$ (extendable to $72 \mathrm{~km}$ ) are considered for this city (Fig. 1). General method statement of Tabriz Urban Railway Line 2 (TURL2) with $20 \mathrm{~km}$ in length expressed that the whole route will be excavated by two TBM. One of them starts from station $A_{2-1}$ toward station $G_{2}$ and the other one starts from station $\mathrm{N}_{2}$ toward station $\mathrm{G}_{2}$. The excavation of the 2 TBMs is oriented in order to meet at the central point of the route in the center of city. Third part - station $\mathrm{O}_{2}$ to $\mathrm{S}_{2}-$ will be excavated by one of them which can finish its first duty. Two kinds of TBM such as EPB (earth pressure balance) and SS (slurry shield) are usually used for urban areas. Therefore choosing TBM between the two kinds such as EPB and SS based on important parameters affecting the machine operation including soil grain size, presence of boulders, hydrogeology condition, presence of cavities, and sticky material will be very important.

The subject of TBM selection has attracted much attention of many researchers recently (among others, Marinos et al. 1998, 2008, 2009; Shahriar et al. 2008; Erickson et al. 2008; Lehner and Hartmann 2007; Imaishi
2007; Lovat 2006; Diponio et al. 2007; Fan and Yu 2005; Anonymous 1995, 2005; Babendererde et al. 2004; Skelhorn 2005; Thewes and Burger 2004; Langmaack 2001, 2002; Nilsen et al. 2006; O'Carroll 2005; Chang et al. 2006; Bilgin et al. 2004; Shang et al. 2004; Farrokh and Rostami 2008; Dowden et al. 2001; Kalamaras et al. 2001; Marinos et al. 1998; Morris and Hansmire 1995; Xu et al. 1996; Sonmez and Ontepeli 2009). The investigations of Marinos et al. (2008) on applicable TBM for western extension of the Athens (both EPB or SS) and applicability of each type of TBM has been discussed using the available data obtained from an extensive site investigation. Shahriar et al. (2008), based on geotechnical risk minimization and a new approach analyzing decisions using decision tree selected a TBM for Nosoud water transfer tunnel (located in Iran) for problems such as encountering fault zones with running and water bearing gouge, tunnel walls instabilities in running or blocky grounds, hard and abrasive rock sections and convergent tunnel sections. Moreover, San Francisco Public Utilities Commission planned to replace 5 miles of pipeline under San Francisco Bay using a tunnel constructed by TBM. In order that the alignment supposed to pass under environmentally sensitive habitats through inter-bedded layers of sands and clays and buried bedrock ridge, Erickson et al. (2008), considering the geotechnical characterization and anticipated tunnelling conditions and various construction 


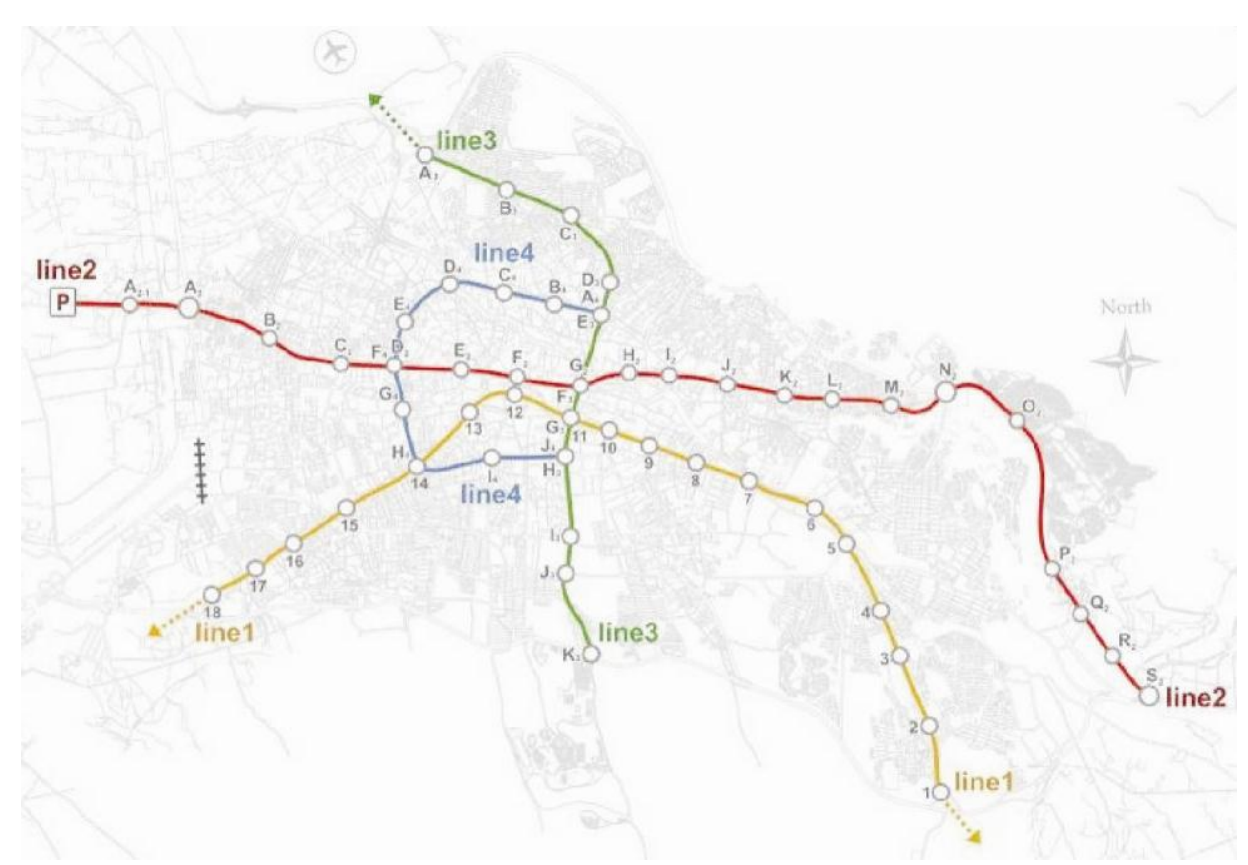

Fig. 1. Tabriz urban railways

methods finally select an EPB TBM described in detail. Also (Lehner and Hartmann 2007) applying fuzzy logic in selection of a tunnel boring machine showed that Fuzzy logic can be used to assist engineers in the process of making decisions, selecting from a range of options or classifying objects.

In this paper, after presenting affected criteria in TBM selection such as technical, economical and environmental objects, appropriate weight to each item is assigned according to engineering judgment. Then considering conditions like maximizing technical adequacy, minimizing excavation risk, costs, excavation duration and environmental impacts, MCA method (Multi Criteria Analysis) is used and finally applicable TBM for TURL2 is selected.

\section{Geological geotechnical context}

The TURL2 alignment can be subdivided in three sections:

1. Western extension: from the depot area to $A_{2-1}$ station about $2 \mathrm{~km}$ long (cut and cover method).

2. Main part: from station $\mathrm{A}_{2-1}$ to $\mathrm{O}_{2}$ about $12.5 \mathrm{~km}$ long (mechanized excavation method).

3. Eastern extension: from station $\mathrm{O}_{2}$ to $\mathrm{S}_{2}$ (final station) about $6.5 \mathrm{~km}$ long. (mechanized excavation method).

Geomorphology of the project region is formed under the effect of tectonic forces, faults, folds and erosion. The North Tabriz fault is located between North Mountains and Tabriz plain. There are many minor faults located at the southern part of the Tabriz city. Erosion and sedimentation are the main factors, affecting the outcrop of the region. Mehran River (Ghoorichay) is one of the most important rivers of the region, which is 200 to 300 meters apart from the investigated corridor, which meet the TURL2 between stations $\mathrm{G}_{2}$ and $\mathrm{H}_{2}$. General geological specifications of different parts of TURL2 are presented in Table 1 .

Table 1. Geological specifications of different parts of the route

\begin{tabular}{l|l}
\hline \multicolumn{1}{c|}{ Zone } & \multicolumn{1}{c}{$\begin{array}{c}\text { Main geological/geotechnical } \\
\text { features }\end{array}$} \\
\hline $\begin{array}{l}\text { From western part to } \\
\text { station } \mathrm{L}_{2} \\
\text { (mid line of main part) }\end{array}$ & $\begin{array}{l}\text { Quaternary deposit } \\
\text { (Variable permeability + grain } \\
\text { size distribution) }\end{array}$ \\
\hline From station $\mathrm{L}_{2}$ to $\mathrm{O}_{2}$ & $\begin{array}{l}\text { Bed Rock (Marlstone + Siltstone + } \\
\text { Sandstone) }\end{array}$ \\
\hline $\begin{array}{l}\text { From station } \mathrm{O}_{2} \text { to } \mathrm{P}_{2} \\
\text { (mid line of eastern part) }\end{array}$ & $\begin{array}{l}\text { Quaternary deposit (Variable } \\
\text { permeability + grain size } \\
\text { distribution) }\end{array}$ \\
\hline $\begin{array}{l}\text { From station } \mathrm{P}_{2} \text { to } \mathrm{S}_{2} \\
\text { (end of eastern part) }\end{array}$ & $\begin{array}{l}\text { Bed Rock (Marlstone + } \\
\text { Siltstone + Sandstone) }\end{array}$ \\
\hline
\end{tabular}

\section{Effective factors of TURL2 mechanized excavation}

The only two suitable TBM for TURL2 construction are EPB an SS TBM's due to urban area with ancient/ important building, underground interferences, critical geotechnical and hydrogeological conditions. General comparison between EPB and SS types of TBM are presented in Table 2. Mechanized excavation of TURL2 tunnel is influenced by geotechnical and environmental items explained as below:

\subsection{Grain size distribution}

Grading test results of TURL2 in main and extension parts are entirely piled up in Figs. 2, 3, 4 and 5 respectively. According the displayed grain size distributions, both the TBM type machines appear applicable with maybe some preference for the Slurry. 
Table 2. General comparison between SS and EPB types of TBM

\begin{tabular}{l|l|l}
\hline \multicolumn{1}{c|}{ Items } & \multicolumn{1}{c}{ SS } & \multicolumn{1}{c}{ EPB } \\
\hline Grain size distribution & Fine sand, sand, gravel & Clay, silt, fine sand, sand \\
\hline Presence of boulders & Use stone crusher & Remove boulders by hand \\
\hline Sticky behavior & Add polymers to slurry & Cutter head opening design \\
\hline Face pressure management & By bentonite slurry pressure & By excavated material pressure \\
\hline Face stability & Controlled by the "liquid" slurry & Controlled by “dense" slurry pressure like a paste \\
\hline Surface settlement & Face support pressure + grout behind segments & Face support pressure + grout behind segments \\
\hline Mucking & Pumped out & Extracted by screw conveyor \\
\hline $\begin{array}{l}\text { Working Cycle } \\
\text { Efficiency }\end{array}$ & $\begin{array}{l}\text { Muck-out by pumps } \\
\text { (continuous) }\end{array}$ & Muck-out by train (not continuous) \\
\hline Maintenance & Chamber entrance possibility from air cushion & Difficulty for chamber entrance \\
\hline Environment & $\begin{array}{l}\text { Ease to separate soil from liquid by separation } \\
\text { plant }\end{array}$ & $\begin{array}{l}\text { Muck can be too liquid and } \\
\text { difficult for transport to disposal areas }\end{array}$ \\
\hline $\begin{array}{l}\text { Ease of operation and } \\
\text { tolerance to operator } \\
\text { experience }\end{array}$ & Need high experience & $\begin{array}{l}\text { Relatively } \\
\text { lower risk level }\end{array}$ \\
\hline \begin{tabular}{l} 
Costs \\
\hline
\end{tabular} & Higher cost because of separation plant & $\begin{array}{l}\text { Operational costs increasing for ground } \\
\text { conditioning necessities }\end{array}$ \\
\hline
\end{tabular}

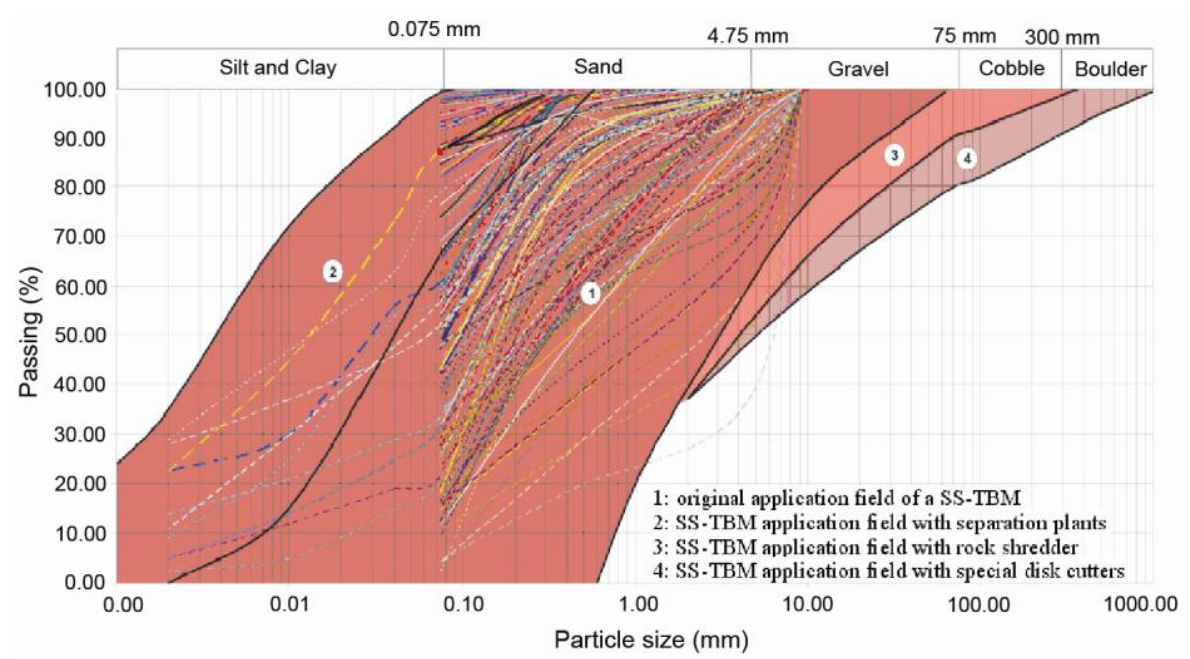

Fig. 2. Grading test results of main part soil on field of SS-TBM

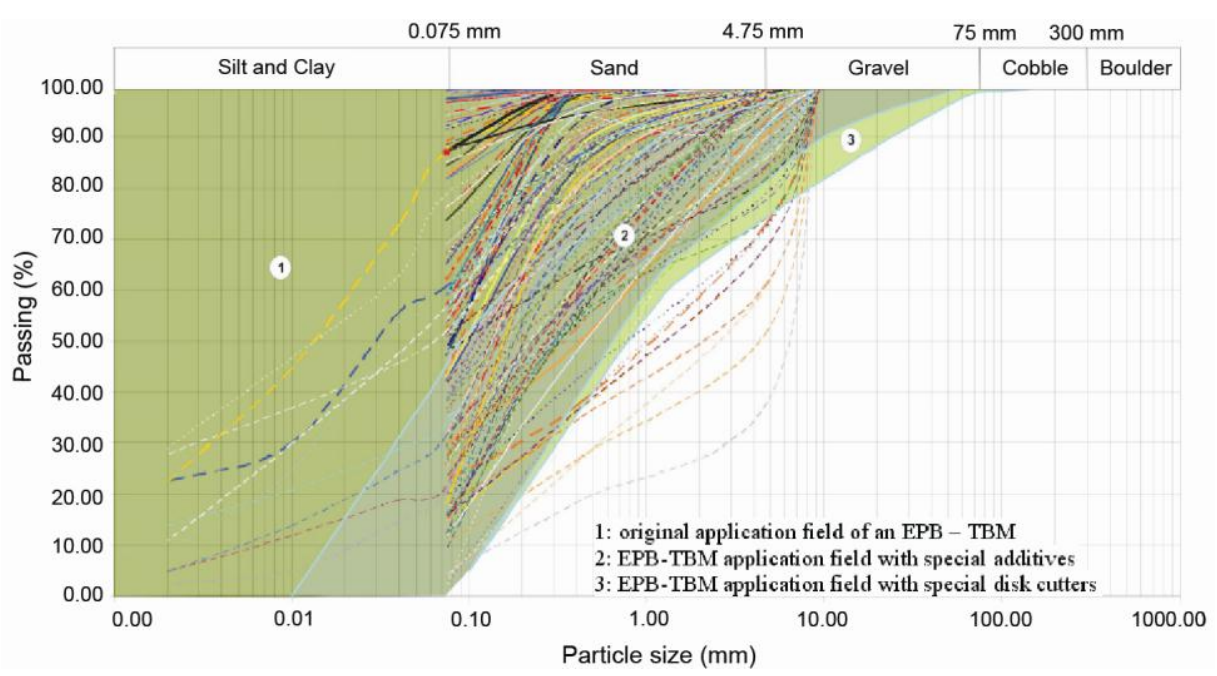

Fig. 3. Grading test results of main part soil on field of EPB-TBM 


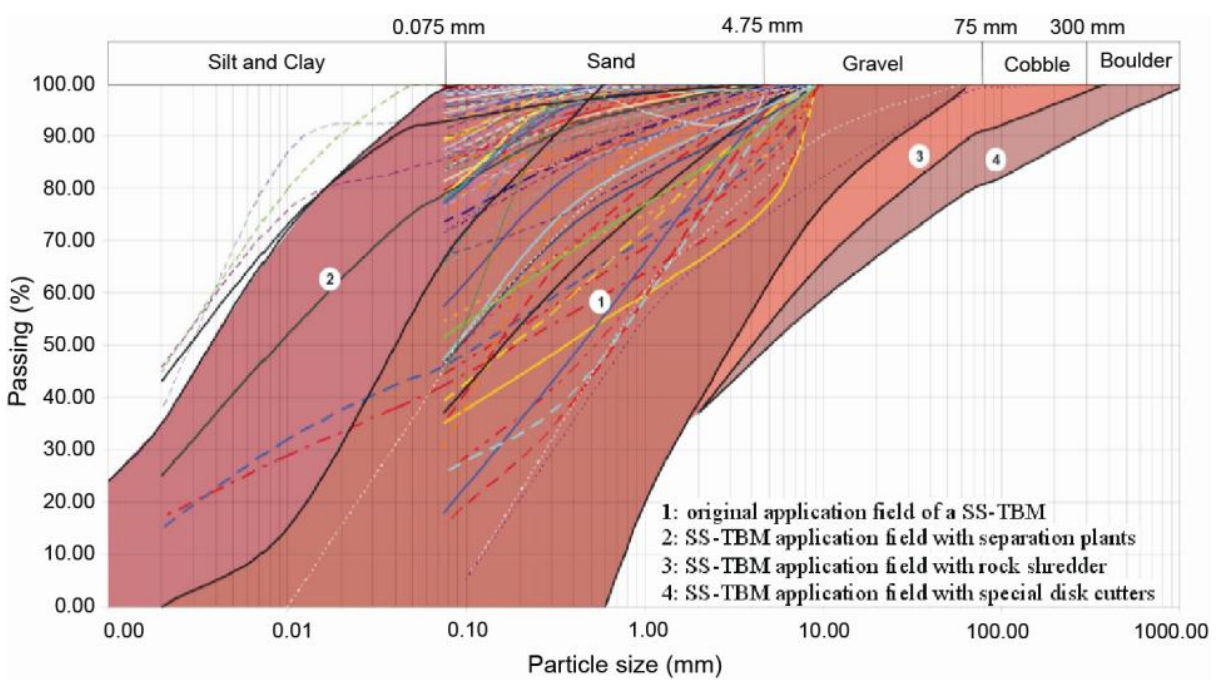

Fig. 4. Grading test results of extension part soil on field of SS-TBM

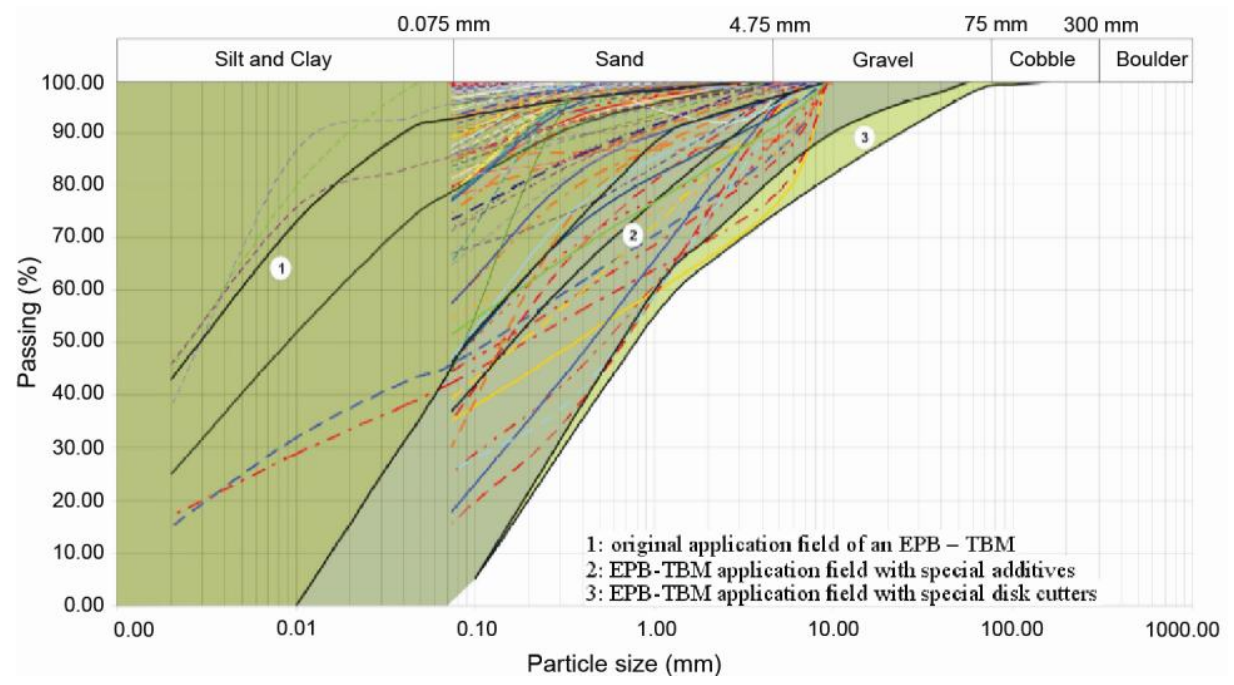

Fig. 5. Grading test results of extension part soil on field of EPB-TBM

\subsection{The presence of boulders}

Historically, boulders are a frequent source of problems in soft ground tunneling. During tunnel construction, breaking and removing boulders manually as obstructions cause delays to the project. A tunnel boring machine (TBM) maintenance can also cause delays. Managing these problems is difficult since normal soil investigation techniques do not accurately predict the presence or frequency of boulders. This has lead to considerable number of claims for extra costs and delays during the construction of soft ground tunneling projects. These issues are exacerbated in pressurized face tunneling systems where there is limited access to the TBM cutter-head for obstruction removal and/or cutter-head maintenance (Diponio et al. 2007; Dowden et al. 2001). Mechanized tunnel excavation of Tabriz subway line 1 (TURL1) was started with low advance rate due to the presence of boulders not passing through the screw conveyor (Fig. 6)

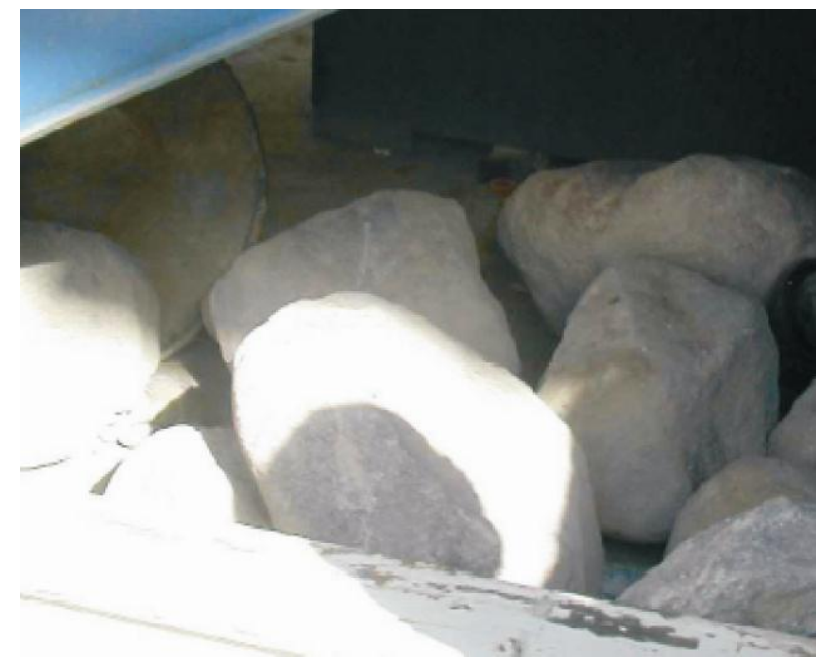

Fig. 6. Some boulders given during TURL1 mechanized excavation 
causing stop of the excavation and requires extra maintenance of the cutting tools. During excavation of TURL1, usually the settlement is zero but it had sudden collapse due to the problems listed above. Due to the presence of Sahand volcanic mountain, the Mehran River has brought along its bed some big boulders (more shallow) and some smaller ones (deeper). The complementary geotechnical investigations on the route of TURL2 have confirmed the presence of boulders both between stations $F_{2}$ and $G_{2}$ and in the eastern part whilst boulder depth estimating is difficult. It is possible to use a stone crusher that can destroy boulder with diameter up to $80-90 \mathrm{~cm}$ inside a SS. An EPB machine with excavation diameter of approx. $10 \mathrm{~m}$ can be equipped with a screw conveyor with diameter around $1 \mathrm{~m}$. In this case the maximum dimension of the boulders extractable inside the muck is about $30-40 \mathrm{~cm}$.

\subsection{The permeability of the ground and the water pressure}

In general it is possible to say that the permeability values are compatible with the usage both TBM's type because the instant pressure produced by such phenomena can be managed by both TBMs. In EPB TBMs a risk can be water inflow into the screw conveyor. Hence it is necessary to have an adequate pressure at the face and a water resistant closing gate. Fig. 7, shows the Permeability test results done in TURL2 geotechnical investigation.

\subsection{The sticky behavior}

When a TBM excavates through zones with high percentage of clays and silts "sticky behavior" occurs which can highly reduce the TBM progress and in some cases even cause a complete stop of the advancement of the tunnel. A simple and efficient method exists for assessing the stickiness of the ground to be excavated, based on the natural water content $\left(\mathrm{W}_{\mathrm{n}}\right)$, plastic limit $\left(\mathrm{W}_{\mathrm{P}}\right)$ and plasticity index $\left(\mathrm{I}_{\mathrm{p}}\right)$. The ground should have a sticky behavior if $\mathrm{W}_{\mathrm{n}} / \mathrm{W}_{\mathrm{p}} \geq 1.0$ and $\mathrm{I}_{\mathrm{p}} \geq 0.25$.
Generally, sticky behavior may strongly influence the cutter head configuration (opening ratio percent), mucking path from the plenum to the first conveyor belt and also torque amount to be supplied to the cutter head (in EBP). Hazard of clogging in muck circulation is so dangerous that the plenum should be designed to ease the movement of muck from its upper part to its lower part (Thewes and Burger 2004).

Thus, the openings in the centre part of the chamber shall be bigger than in the external part because in the central part of the plenum the speed is the lowest. The experiences show that a cutter-head clogging start in this central part where the tangential speed of the cutter-head is rather low and consequently the excavated material is relatively slow and results initiation of front cutter-head clogging which increases until complete blockage of advance. A wider open center design also limits the wear on the cutter-head structure and increasing the flow of the material and these phenomena increase cutter-head torque and required thrust and eventually put severe limits on the TBM advance rate. For appropriate design of cutter-head, injection of additives to the front or in the cutter chamber should be implemented wherever necessary.

\subsection{The risk of gas}

According to geotechnical investigations, $\mathrm{CO}_{2}$ has been encountered near station $\mathrm{M}_{2}$ which is very risky for the safety of the personnel working inside the tunnel. Hence flameproof machinery and an adequate air monitoring system will be necessary for both 2 TBMs.

\subsection{Required space for separation plants}

The SS requires an area to install of at least $10.000 \mathrm{~m}^{2}$ which is not available in Tabriz. So, this subject will be a negative score for SS TBM.

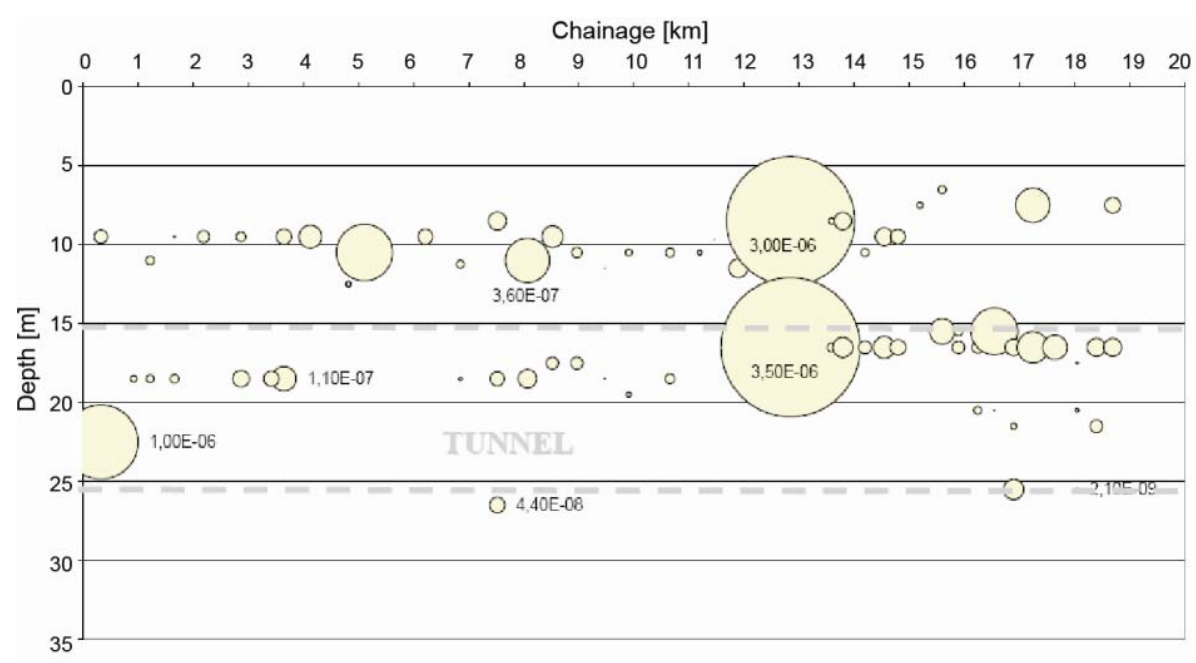

Fig. 7. Permeability test results done in TURL2 geotechnical investigation 


\subsection{The closed face TBM's type experience in Iran}

Actually in Iran there are 8 TBMs with face support and all of them are EPB. It must be considered that foreign personnel is difficulty available in Iran for this reason also considering the complexity of conditioning slurry it is necessary to consider properly the lack of experience as a major item to choice. The correct choice of machine without the correct management and operating controls is as bad as choosing the wrong type of machine for the project (BTS/ICE 2005).

\subsection{The suitable TBM's costs}

From cost point of view, the cost of SS and EPB types of TBM including TBM, Back-up system and auxiliary equipments is 22 and 17 million Euro respectively.

\section{MCA (Multi Criteria Analysis) concept}

The comparative evaluation of alternative scenarios on the basis of different criteria requires special tools that allow the comparison of different subject inside a unique system. The MCA method is suitable to solve this kind of feature and to provide a scheme where different themes (the criteria) shall be taken into account simultaneously (Guglielmetti et al. 2008).

This method allows the direct comparison between alternatives using a numerical index. MCA method allows calculating a performance index for each alternative. Each column of the performance matrix (criteria) can be transformed in a utility scale $\left(u_{j}\right)$ varying from 0 to 1 where 0 represents the worst performance and 1 represents the best performance.

The utility $(U)$, or rating, of each alternative $(x)$ is calculated as the sum of the values coming form each criteria normalized to its weight $\left(P_{i}\right)$ :

$$
U_{x}=\sum_{i, j}^{n} u_{j} * P_{i} .
$$

The weights allow defining the relative importance of each factor compared to the others.

$$
\sum_{i}^{n} P_{i}=1 .
$$

Based on expressed important items the weight of each criterion is presented in Table 3.

\section{Comparison between EPB and SS using MCA method}

Most important objects in MCA comparison method are:

- To maximize the technical adequacy (reduction of construction time);

- To minimize the costs;

- To minimize the environmental impact.

The line with varying length and relative weights is reported in Table 4.
Table 3. The weights assigned to each criterion based on Tabriz

\begin{tabular}{|c|c|c|}
\hline Sub-Goals & Criteria & Weight \\
\hline \multirow{6}{*}{$\begin{array}{l}\text { Technical } \\
\text { Adequacy } \\
\text { (affecting } \\
\text { construction } \\
\text { time) }\end{array}$} & Grain size distribution & 0.15 \\
\hline & Presence of boulder & 0.4 \\
\hline & Presence of cavity & 0.2 \\
\hline & Sticky material & 0.05 \\
\hline & Hydrogeological condition & 0.15 \\
\hline & Water inrush & 0.05 \\
\hline \multirow[t]{2}{*}{ Costs } & $\begin{array}{l}\text { Cost for TBM furniture and } \\
\text { assembly }\end{array}$ & 0.4 \\
\hline & Cost of excavation of each part & 0.6 \\
\hline \multirow{3}{*}{$\begin{array}{l}\text { Environmental } \\
\text { Impact }\end{array}$} & Land occupancy & 0.5 \\
\hline & Muck disposal & 0.25 \\
\hline & Aquifer protection & 0.25 \\
\hline
\end{tabular}
condition

Table 4. The length and relative weights of each part of TURL2

\begin{tabular}{l|l|c|c|c}
\hline Sub-Goals & Criteria & $\begin{array}{c}\text { Geotechnical } \\
\text { condition }\end{array}$ & $\begin{array}{c}\text { Distance } \\
(\mathrm{m})\end{array}$ & $\begin{array}{c}\text { Weight } \\
(\%)\end{array}$ \\
\hline \multirow{4}{*}{$\begin{array}{l}\text { Main } \\
\text { Part }\end{array}$} & $\begin{array}{l}\text { Station } \\
\mathrm{A}_{2-1} \text { to } \mathrm{G}_{2}\end{array}$ & Soils & 7040 & 39 \\
\cline { 2 - 5 } & $\begin{array}{l}\text { Station } \\
\mathrm{G}_{2} \text { to } \mathrm{O}_{2}\end{array}$ & $\begin{array}{c}\text { Soil with } \\
\text { boulder }\end{array}$ & 6485 & 36 \\
\hline \multirow{4}{*}{$\begin{array}{l}\text { Extension } \\
\text { Part }\end{array}$} & $\begin{array}{l}\text { Station } \\
\mathrm{O}_{2} \text { to } \mathrm{P}_{2}\end{array}$ & $\begin{array}{l}\text { Soil with } \\
\text { boulder }\end{array}$ & 3070 & 17 \\
\cline { 2 - 5 } & $\begin{array}{l}\text { Station } \mathrm{P}_{2} \\
\text { to } \mathrm{S}_{2}\end{array}$ & Rock & 1420 & 8 \\
\hline
\end{tabular}

The grain size distribution appears to be most suitable for a SS TBM. Only in the eastern part in the final zone of excavation through marlstone an EPB TBM is preferable. Generally EPB TBM is adaptable to the route by means of some additives.

The risk of boulders is predictable from the G2 station up to the start of the marlstone in the eastern part and a SS TBM is much preferable in this condition to an EPB TBM.

The presence of cavities is a risk especially dealing with the centre of the city where usually exist wells or manholes for ancient sewerage lines. These structures shall be very dangerous for a SS TBM because if such a TBM encounters them during excavation it may cause a loss of pressure at the face with risk of high settlements and/or collapses affecting the surroundings structures. Moreover loss of slurry inside wells may exit of it to the surface or cause groundwater pollution.

The sticky behavior is a hazard along the line that can cause low advance rate and SS TBM is a bit preferable for this hazard. Anyway the difference between these two systems in these conditions is almost negligible. For an EPB the eventual occurrence of water inrush cannot be excluded if the excavation chamber is not full of saturated material with consequent risk of stoppage of the advancement and even safety problems for the workers. The overall comparison of the two alternatives with respects to the different criteria is summarized in Table 5. 
Table 5. Overall comparison of the two alternatives

\begin{tabular}{|c|c|c|c|c|c|c|c|c|c|c|}
\hline & \multirow{2}{*}{\multicolumn{2}{|c|}{$\frac{\text { Station } A_{2-1} \text { to } G_{2}}{\text { Weight }=0.39}$}} & \multirow{2}{*}{\multicolumn{2}{|c|}{$\begin{array}{c}\text { Station } \mathrm{G}_{2} \text { to } \mathrm{O}_{2} \\
\text { Weight }=0.36\end{array}$}} & \multirow{2}{*}{\multicolumn{2}{|c|}{$\begin{array}{l}\text { Station } \mathrm{O}_{2} \text { to } \mathrm{P}_{2} \\
\text { Weight }=0.17\end{array}$}} & \multirow{2}{*}{\multicolumn{2}{|c|}{$\begin{array}{l}\text { Station } \mathrm{O}_{2} \text { to } \mathrm{N}_{2} \\
\text { Weight }=0.08\end{array}$}} & \multirow{2}{*}{\multicolumn{2}{|c|}{$\begin{array}{l}\text { Overall } \\
\text { Ratings }\end{array}$}} \\
\hline & & & & & & & & & & \\
\hline & EPB & SS & EPB & SS & EPB & SS & EPB & SS & EPB & SS \\
\hline Grain Size Distribution & 0.8 & 1 & 0.8 & 1 & 0.8 & 1 & 1 & 0.8 & 0.82 & 0.98 \\
\hline Presence of Boulders & 1 & 1 & 0.2 & 1 & 0.2 & 1 & 1 & 1 & 0.58 & 1 \\
\hline Presence of Cavities & 1 & 0.5 & 1 & 0.5 & 1 & 1 & 1 & 1 & 1 & 0.63 \\
\hline Sticky Behavior & 0.8 & 1 & 0.8 & 1 & 0.8 & 1 & 0.8 & 1 & 0.8 & 1 \\
\hline Hydrogeological condition & 0.8 & 1 & 0.8 & 1 & 0.8 & 1 & 1 & 1 & 0.82 & 1 \\
\hline Water inrush & 1 & 1 & 0.8 & 1 & 1 & 1 & 0.8 & 1 & 0.91 & 1 \\
\hline
\end{tabular}

Table 6. Final making decision about EPB or SS for TURL2 mechanized excavation

\begin{tabular}{l|c|c}
\hline Sub-goals $\downarrow \quad$ Alternatives $\rightarrow$ & EPB & SS \\
\hline Technical adequacy (T) & 0.763 & 0.923 \\
\hline Costs (C) & 1 & 0.792 \\
\hline Environmental Impact (E) & 1 & 0.675 \\
\hline
\end{tabular}

Table 7. Sensitivity analysis final making decision about EPB or SS

\begin{tabular}{c|c|c}
\hline Scenario & EPB & SS \\
\hline $\mathrm{T}=0.33 ; \mathrm{C}=0.33 ; \mathrm{E}=0.33$ & 0.921 & 0.797 \\
\hline $\mathrm{T}=0.50 ; \mathrm{C}=0.25 ; \mathrm{E}=0.25$ & 0.882 & 0.828 \\
\hline $\mathrm{T}=0.25 ; \mathrm{C}=0.50 ; \mathrm{E}=0.25$ & 0.941 & 0.796 \\
\hline $\mathrm{T}=0.25 ; \mathrm{C}=0.25 ; \mathrm{E}=0.50$ & 0.941 & 0.766 \\
\hline $\mathrm{T}=1.00 ; \mathrm{C}=0.00 ; \mathrm{E}=0.00$ & 0.763 & 0.923 \\
\hline $\mathrm{T}=0.00 ; \mathrm{C}=1.00 ; \mathrm{E}=0.00$ & 1 & 0.792 \\
\hline $\mathrm{T}=0.00 ; \mathrm{C}=0.00 ; \mathrm{E}=1.00$ & 1 & 0.675 \\
\hline
\end{tabular}

Based on Table 6, it is obvious that EBP TBM will be more appropriate than SS TBM for TURL2 excavation. The rating of the main goal "Best choice of the TBM" is evidently related to the weight assigned to each sub-goal. Considering the subjectivity of such estimation, a sensitivity analysis has been performed considering different scenarios of assignments. In Table 7, the results of the multi-criteria analysis according the different scenarios are summarized, including also for completeness the case of absolute preference for each sub-goal already shown in Table 6. According to the Table 7, only one scenario suggests using SS TBM whereas we consider only technical aspect. It proves that considering all aspects including $\mathrm{C}$ and $\mathrm{E}$ it is appropriate to choose $\mathrm{EPB}$ TBM.

\section{Conclusion}

Choosing TBM process for Tabriz Urban Railway Line 2 (TURL2) using multi criteria analysis (MCA) is expressed in this paper. Generally it is possible to say that in the excavation through soft soils in urban areas the TBM should be chosen between EPB TBM and SS Using multi criteria analysis (MCA) method. It is identified that technical, economical and environmental criteria affect the TBM type. Site investigation and other line of Tabriz experiences show that the most important parameters affecting TBM type will be grain size distribution, presence of boulder, permeability and water pressure, soil sticky behavior, risk of gas, required space for separation plants. Based on significance of each criterion, a specified weight is assigned. From technical point of view the experience from TURL1 in presence of boulders affirms that boulders in Tabriz are the most important problem for mechanized excavation. For this reason the use of a SS TBM seams to be preferable. On the other hand SS presents some general disadvantages such as necessity of experienced team, major spaces for separation plants, major consumes and purchasing costs.

In any case technical specification is valuable both for EPB and SS TBMs but it is very important that the manufacturer should propose machine which can operate in presence of boulders without continuous prolonged stoppages and/or having face instabilities that may cause damage to the surroundings. Therefore EPB TBM plus some additives is more appropriate for TURL2 excavation.

\section{References}

Anonymous. 1995. Review of alternative construction methods and feasibility of proposed methods for constructing Attiko Metro Extension of Line 3 to Egaleo. Attiko Metro S.A, Greece, Geodata S.p.A.

Anonymous. 2005. Closed face tunnelling machines and ground stability, A guideline for best practice. British Tunnelling Society-Institution of Civil Engineers, Thomas Telford Publishing.

Babendererde, S.; Hoek, E.; Marinos, P.; Cardoso, A. 2004. Geological risk in the use of TBMs in heterogeneous rock masses-the case of "Metro do Porto" and the measures adopted. Workshop in Aveiro, Portugal.

Bilgin, N.; Dincer, T.; Copur, H.; Erdogan, M. 2004. Some geological and geotechnical factors affecting the performance of a roadheader in an inclined tunnel, Tunnelling and Underground Space Technology 19(6): 629-636. doi:10.1016/j.tust.2004.04.004

BTS (British Tunnelling Society) /ICE 2005. Closed face tunneling machine and ground stability- a guideline for best practice, Thomas Telford Publishing.

Chang, S.; Choi, S.; Bae, G.; Jeon, S. 2006. Performance prediction of TBM disc cutting on granitic rock by the linear cutting test, Tunnelling and Underground Space Technology 21(3-4): 1-271.

Diponio, M.; Chapman, D.; Bournes, C. 2007. EPB tunnel boring machine design for boulder conditions, in Proceedings of the Rapid Excavation and Tunneling Conference, chapter 20 - Difficult Ground Conditions II, 14. 
Dowden, P.; Peter, B.; Robinson, B.; Robert, A. 2001. Coping with boulders in soft ground TBM tunneling, in Proceedings of Rapid Excavation and Tunneling Conference, chapter 78 - Difficult Ground, 961-977.

Erickson, L.; Raleigh, P.; Romero, V. 2008. Geotechnical conditions and TBM selection for the Bay tunnel, in Proceedings North American Tunneling 2008, 389-398.

Fan, W.; Yu, C. 2005. Analysis of TBM cycle time in the hsuehshan tunnel, in Proceedings of the World Long Tunnels Conference, 211-222.

Farrokh, E.; Rostami, J. 2008. Correlation of tunnel convergence with TBM operational parameters and chip size in the Ghomroud tunnel, Iran, Tunnelling and Underground Space Technology 23(6): 700-710. doi:10.1016/j.tust.2008.01.005

Guglielmetti, V.; Mahtab, A.; Xu, S. 2008. Mechanized tunneling in urban areas. Taylor and Francis group, editors geodata company.

Imaishi, T. 2007. Tunneling in urban area by slurry type TBM. Railway Bosphorus Tube Crossing Tunnels and Stations, 3rd training course tunneling in urban area, Prague.

Kalamaras, G.; Brino, L.; Carrieri, G.; Pline, C.; Grasso, P. 2001. Application of multicriteria analysis to select the best highway alignment, Tunnelling and Underground Space Technology 15(4): 415-420. doi:10.1016/S0886-7798(01)00010-4

Langmaack, L. 2002. Soil conditioning for TBM chances \& limits, in AFTES (French Association of Tunnelling and Underground Space). AFTES - Toulouse, 21-23 October 2002, 207-210.

Langmaack, L. 2001. Europe and Asia: Application of new TBM conditioning Additives, BAUMA 2001.

Lehner, K.; Hartmann, D. 2007. Using knowledge-based Fuzzy Logic components in the design of underground engineering structures, in ECCOMAS Thematic Conference on Computational Methods in Tunneling (EURO: TUN), Vienna, Austria, August 27-29 2007, 1-13.

Lovat, R. P. 2006. TBM Design Considerations: Selection of earth pressure balance or slurry pressure balance tunnel boring machines, TBM design considerations for projects, in International Symposium on Utilization of Underground Space in Urban Areas, Sharm-El-Sheikh, Egypt, November 6-7 2006.

Marinos, P. G.; Novack, M.; Benissi, M.; Stoumpos, G.; Papouli, D.; Panteliadou, M.; Marinos, V.; Boronkay, K.; Korkaris, K. 2009. Assessment of ground conditions with respect to mechanised tunnelling for the construction of the extension of the Athens metro to the city of Piraeus, Bulletin of Engineering Geology and the Environment 68(1): 17-26. doi:10.1007/s10064-008-0183-9

Marinos, P. G.; Novack, M.; Benissi, M.; Panteliadou, M.; Papouli, D.; Stoumpos, G.; Marinos, V.; Korkaris, K. 2008. Ground information and selection of TBM for the Thessaloniki metro, Environmental and Engineering Geoscience 14(1): 17-30. doi:10.2113/gseegeosci.14.1.17

Marinos, P.; Antoniou, A.; Novack, M.; Benissi, M.; Rovolis, G.; Papadatos, I.; Agelidaki, K. 1998. TBM excavation in weak and heterogeneous rock masses for the Athens metro, in Proceedings of the 8th International Congress of $I A E G$, Balkema Publication, Vancouver, Canada 1998, 3513-3522.

Morris, J.; Hansmire, W. 1995. TBM Tunneling on the Yucca Mountain project, in Proceedings Rapid Excavation and Tunneling Conference, chapter 51: 807-822.

Nilsen, B.; Dahl, F.; Holzhaeuser, J.; Raleigh, P. 2006. Abrasivity of soils in TBM tunneling, Tunnels and Tunneling International, 36-38.

O'Carroll, J. B. 2005. A Guide to Planning, Constructing and Supervising Earth Pressure Balance TBM Tunneling, Parsons Brinckerhoff.

Shahriar, K.; Sharifzadeh, M.; Khademi, J. 2008. Geotechnical risk assessment based approach for rock TBM selection in difficult ground conditions, Journal of Tunneling and Underground Space Technology 23(3): 318-325. doi:10.1016/j.tust.2007.06.012

Shang, Y.; Xue, J.; Wang, S.; Yang, Z.; Yang, Y. 2004. A case history of tunnel boring machine jamming in an interlayer shear zone at the Yellow River diversion project in China, Engineering Geology 71(3-4): 199-211. doi:10.1016/S0013-7952(03)00134-0

Skelhorn, S. 2005. Edmonton South LRT twin tunnels, in Proceedings of the Rapid Excavation and Tunneling Conference, Chapter 24. Pressure Face Tunneling, 10.

Sonmez, R.; Ontepeli, B. 2009. Predesign cost estimation of urban railway projects with parametric modeling, Journal of Civil Engineering and Management 15(4): 405-409. doi:10.3846/1392-3730.2009.15.405-409

Thewes, M.; Burger, W. 2004. Clogging risks for TBM drives in clay, Tunnels \& Tunnelling International, 28-31.

Xu, S.; Mahtab, A.; Grasso, P. 1996. The use of aided decision techniques in tunnel design. Gallerie e Grandi opera in sotterraneo. Luglio.

\section{TABRIZO METRO TGM PARINKIMAS TAIKANT DAUGIATIKSLİ SPRENDIMŲ PRIĖMIMO METODĄ}

\section{K. Edalat, M. J. Vahdatirad, H. Ghodrat, S. Firouzian, A. Barari}

S antrauka

Požemine inžinerija ir statyba labai išplito bei ịgijo aukšto lygmens patirtị tunelių statyboje ėmus naudoti tunelių gręžimo mašinas (TGM). Šis statybos būdas taikytas statant daug tunelių, kurie vis ilgęja, gilèja ir platėja pagal skersmenį, t. y. statyba realizuojama sunkiau. Tabrize - viename iš didžiausių šiaurès vakarų Irano miestų - yra keturios statomos arba planuojamos statyti metro linijos. Tabrizo miesto geležinkelio 2-os linijos (TMG2L) pirmoji projektavimo fazė yra baigta. Jos ilgis - 20 km, daug jos atkarpų eina po žeme. Požeminèms atkarpoms pastatyti gali būti naudojamos dviejų tipų TGM. Tai žemès slėginès pusiausvyros mašina (ŽSPM) arba suspensijos skydo mašinos (SSM). Šiame straipsnyje nagrinèjamas TGM pasirinkimas tarp ŽSPM ir SSM taikant daugiatikslį sprendimų prièmimo metodą (DSPM). Šiam metodui pritaikyti apibrěžiami tam tikri techniniai, ekonominiai ir aplinkos rodikliai, darantys įtaką TGM tipui. Rodikliams priskiriami svoriai. DSPM taikymo rezultatai parodė, kad ŽSPM yra tinkamesnè TMG2L kasti.

Reikšminiai žodžiai: mechanizuotas tunelio kasimas, TGM, Tabrizo metro, daugiatikslis sprendimų prièmimas, TMG2L. 
Kamaladdin EDALAT has got a Master of Science in Mining Engineering from Science \& Research branch of Azad University and is studying Master of Science in geotechnical engineering in Zanjan branch of Azad University.

His research interests include the Mechanized tunnelling, stability analysis in structures built in soil and rock and foundation design. He is a member of Iranian tunnel institute and Iranian rock mechanic institute.

Mohammad Javad VAHDATIRAD is a researcher at Department of Civil Engineering, Aalborg University, Denmark. He has been member of ACI since 2005. His research interests include Soil Liquefaction, Settlement Risk Analysis, Mechanized Tunneling, Soil Improvement and Slope Stability.

Hadi GHODRAT is a Master of Science in civil engineering (Geotechnics) from Engineering Faculty at Tarbiat Moallem University of Tehran, I. R. Iran. He is a member of Iran Tunnel Association (IRTA) and Iranian Committee on Large Dams (IRCOLD). He researches on optimization of geotechnical investigations and soil improvement methods used in the projects such as ones could be applied in interaction of problematic soils and underground structures specially tunnels.

Sarah FIROUZIAN is a Master of Science in Geotechnical Engineering from Babol University of Technology, Babol, Iran. Her research interests include Soil Liquefaction, Geotechnical investigations, Mechanized tunneling, Soil Improvement and Settlement Risk Analysis.

Amin BARARI is a researcher at Department of Civil Engineering, Aalborg University, Denmark. He is executive editor and founder of Mechanical Sciences Journal, published by Copernicus. Moreover, he is associate editor in Central European Journal of Engineering published by Versita and Springer. His research interests include Nonlinear Mechanics, Vibrations, Slope Stability, Landslides and Offshore Foundations. 